\title{
Extraction, characterization, and optimization of biodiesel production from Pachira
}

\section{aquatica Aubl}

\author{
Extração, caracterização e otimização da produção de biodiesel da Pachira aquatica Aubl \\ Extracción, caracterización y optimización de la producción de biodiésel de Pachira aquatica Aubl
}

Received: 10/08/2021 | Reviewed: 10/16/2021 | Accept: 12/17/2021| Published: 12/23/2021

\author{
Gabriel Matsuda \\ ORCID: https://orcid.org/0000-0001-5453-644X \\ Universidade Estadual do Oeste do Paraná, Brasil \\ E-mail: gabriel.matsuda@unioeste.br \\ Samuel Nelson Melegari de Souza \\ ORCID: https://orcid.org/0000-0002-3581-902X \\ Universidade Estadual do Oeste do Paraná, Brasil \\ E-mail: samuel.souza@unioeste.br \\ Reinaldo Aparecido Bariccatti \\ ORCID: https://orcid.org/0000-0002-9780-9409 \\ Universidade Estadual do Oeste do Paraná, Brasil \\ E-mail: bariccatti@yahoo.com.br \\ Julio Cezar Girardi \\ ORCID: https://orcid.org/0000-0002-9940-2805 \\ Universidade Estadual do Oeste do Paraná, Brasil \\ E-mail: juliocgirardi@gmail.com \\ Helder Rodrigues da Silva \\ ORCID: https://orcid.org/0000-0003-0679-4692 \\ Universidade Estadual de Londrina, Brasil \\ E-mail: heldersrodrigues@hotmail.com \\ Carmen Luisa Barbosa Guedes \\ ORCID: https://orcid.org/0000-0002-8490-7130 \\ Universidade Estadual de Londrina, Brasil \\ E-mail: carmen@uel.br \\ Luciene Kazue Tokura \\ ORCID: https://orcid.org/0000-0001-9758-0141 \\ Universidade Estadual do Oeste do Paraná, Brasil \\ E-mail: lucienetokura@gmail.com
}

\begin{abstract}
Given the great energy demand to meet the needs of modern society, it is essential that new alternatives to replace fossil diesel are studied. And biodiesel is an alternative that has been gaining prominence on the world stage, mainly with the use of vegetable oils with a high lipid content, such as Pachira aquatica Aubl, also known as munguba. Given the above, the objective of this work was to extract the oil from the seeds of Pachira aquatica, evaluate the physicochemical characteristics of the oil and define the best conditions for catalytic mixing with temperature variation in the production of biodiesel from the oil obtained. Thus, the acidity index, saponification, refraction, peroxide, water content and fatty acid profile of the oil were evaluated. Fourteen treatments of biodiesel produced with different amounts of sulfuric acid and temperature were evaluated. They were analyzed for water content, specific mass, kinematic viscosity at $40{ }^{\circ} \mathrm{C}$, refractive index and ester content. It was found that the lipid content of Pachira aquatica seeds was $42.19 \%$ and its physical chemistry analysis showed that it can be used in the production of biofuels. There was a greater presence of saturated fatty acids, with a predominance of palmitic acid with $81.95 \%$. Biodiesel produced from oil, on the other hand, showed higher production of esters in relation to the volume used at temperatures of $60^{\circ} \mathrm{C}$ and $0.6 \mathrm{~mL}$ of sulfuric acid, and that its properties showed that the plant can be a possible alternative for the production of biodiesel.
\end{abstract}

Keywords: Biofuel; Munguba; Physical chemistry analysis.

\section{Resumo}

Dada a grande demanda de energia para atender às necessidades da sociedade moderna, é essencial que novas alternativas para substituir o diesel fóssil sejam estudadas. E o biodiesel é uma alternativa que vem ganhando destaque no cenário mundial, principalmente com o uso de óleos vegetais com alto teor lipídico, como a Pachira aquatica Aubl, também conhecida como munguba. Diante do exposto, o objetivo deste trabalho foi extrair o óleo das sementes da Pachira aquatica, avaliar as características físico-químicas do óleo e definir as melhores condições para a mistura catalítica com variação de temperatura na produção de biodiesel a partir do óleo obtido. Assim, foram avaliados o índice de acidez, saponificação, refração, peróxido, teor de água e perfil de ácidos graxos do óleo. Foram avaliados 14 
tratamentos de biodiesel produzido com diferentes quantidades de ácido sulfúrico e temperatura. Foram analisados o teor de água, massa específica, viscosidade cinemática a $40{ }^{\circ} \mathrm{C}$, índice de refração e teor de éster. Verificou-se que o teor de lipídico das sementes de Pachira aquatica foi de $42,19 \%$ e sua análise físico-química mostrou que pode ser utilizado na produção de biocombustíveis. Houve maior presença de ácidos graxos saturados, com predominância de ácido palmítico com $81,95 \%$. O biodiesel produzido a partir de óleo, por outro lado, apresentou maior produção de ésteres em relação ao volume utilizado a temperaturas de $60^{\circ} \mathrm{C}$ e $0,6 \mathrm{~mL}$ de ácido sulfúrico, e que suas propriedades mostraram que a planta pode ser uma possível alternativa para a produção de biodiesel.

Palavras-chave: Biocombustível; Munguba; Análise físico-química.

\section{Resumen}

Dada la gran demanda de energía para satisfacer las necesidades de la sociedad moderna, es esencial que se estudien nuevas alternativas para sustituir al diésel fósil. Y el biodiésel es una alternativa que viene ganando destaque en el escenario mundial, principalmente con el uso de aceites con alto contenido lipídico, como la Pachira aquatica Aubl, conocida como Munguba. El objetivo del trabajo fue extraer el aceite de las semillas de la Munguba, evaluar las características fisicoquímicas del aceite y definir las mejores condiciones para la mezcla catalítica con variación de temperatura en la producción de biodiésel. Por lo tanto, se evaluó el índice de acidez, saponificación, refracción, peróxido, contenido de agua y perfil de ácidos grasos del aceite. Se evaluaron 14 tratamientos de biodiésel producido con diferentes cantidades de ácido sulfúrico y temperatura. Se analizó el contenido de agua, la masa específica, la viscosidad cinemática a $40^{\circ} \mathrm{C}$, el índice de refracción y el contenido de éster. Se verificó que el contenido de lípidos de las semillas de Munguba fue de 42,19\% y su análisis físico-químico mostró que puede ser utilizado en la producción de biocombustibles. Hubo mayor presencia de ácidos grasos saturados, con predominio de ácido palmítico con 81,95\%. El biodiésel producido a partir de aceite, por otra parte, presentó mayor producción de ésteres en relación con el volumen utilizado a temperaturas de $60^{\circ} \mathrm{C}$ y $0,6 \mathrm{ml}$ de ácido sulfúrico, y sus propiedades han demostrado que la planta puede ser una posible alternativa a la producción de biodiésel.

Palabras clave: Biocombustible; Munguba; Análisis fisicoquímico.

\section{Introduction}

Among the viable alternatives, biodiesel appears as the main alternative to replace petroleum. The similarity of the properties of biodiesel from oil and fat to petroleum makes its potential favorable as a fuel. The main compatible characteristics are related to the cetanes number, heat of combustion, pour point, kinematic viscosity, and oxidative stability (Knothe, Gerpen \& Krahl, 2005).

To obtain biodiesel it is necessary that raw materials go through chemical processes, in order to eliminate unwanted characteristics. Transesterification is the main method for the production of biodiesel, in which a triacylglyceride reacts with an alcohol in the presence of a catalyst, acid or basic, producing a mixture of fatty acid and glycerol esters (Ma \& Hanna, 1999; Lima Filho, Gouveia, Ruzene \& Silva, 2017; Vieira, Sousa, Rosas, Lima Ronconi \& Mota, 2018).

In Brazil, studies with vegetable oils have emerged after the First World War (Rico \& Sauer, 2015). Since 2006, Brazil has been a self-sufficient country in oil supply, thus, the use of biofuels is thanks to the discussion on climate change and due to the attempt to increase renewable energies to reduce carbon dioxide emissions $\left(\mathrm{CO}_{2}\right)$ (Kohlhepp, 2010). According to the National Agency for Petroleum, Natural Gas and Biofuels - ANP, approximately $18 \%$ of all fuel consumed in Brazil is currently renewable (ANP, 2019). In 2020, biodiesel production was 6,434,453 $\mathrm{m}^{3}$ (ANP, 2020).

Vegetable oils are the main sources of raw materials for the production of biodiesel. Brazil, being a country with a huge territorial extension and with diversity of raw materials, such as soy, sunflower, palm oil, macaúba, peanuts, in addition to more than 350 plant species with great potential for use in the production of biodiesel, has stood out in this regard (Ramos et al., 2017).

Brazil has throughout its wide territory several raw materials for the production of biodiesel, most commonly soy (Ferrari, Oliveira \& Scabio, 2005). Even though soybean is the oilseed that is most used in biodiesel production in the country, it still contains a low percentage of oil in its seeds, causing other raw materials, with higher oil contents, to be used (Cavalett $\&$ Ortega, 2009). Oleaginous plants usually have high oil content, such as soybeans (21\%), palm (22\%), castor beans (59.8\%) and babassu (60\%) (Bergmann et al., 2013). 
The major raw materials used for the production of biofuels are also used in the food industry, which leads to some issues: increase of the prices, focus on the development of monocultures and concentration of agricultural production (Matos, Ninaut, Caiado \& Salvi, 2008; Mitchell, 2008).

Due to the great biodiversity and the strong incentive to socio-environmental development in a sustainable way, the Brazilian Amazon is among the regions with the greatest potential for the development of energy crops with low impact on the food industry and regional ecology. And one of these potential species is Pachira aquatica.

Pachira aquatica Aubl popularly known as munguba is a tree found in the Brazilian Amazon region (Figure 1), in the contours of rivers and streams, however it has an easy adaptation to cultivation in different edaphic and climatic conditions. In the states of São Paulo and Rio de Janeiro, they were introduced into urban afforestation as ornamental plants. It is a tree of fast growth and medium size (Lorenzi, 1992; Silva, Alves, Matos \& Bruno, 2012).

The fruits of Pachira aquatica have an average length of $20 \mathrm{~cm}$ and weight of $710 \mathrm{~g}$, and around 38 seeds per fruit (Camacho, Tatis \& Ayala, 2018; Vinagre et al., 2019) (Figure 1). The seeds are edible and have high levels of protein and oil, which can be an alternative for the production of biofuels. According to Jorge and Luzia (2012) the seeds have a high content of saturated fatty acids, especially palmitic acid. In their studies, Silva, Borges e Antoniosi Filho (2015) found high levels of lipids (46.62\%) and proteins (13.75\%) in the seeds of Pachira aquatica.

Figure 1. Presence of Pachira aquatica Aubl in the regions highlighted in Red on the map (A), tree height (B) and seed characteristics $(\mathrm{C})$.

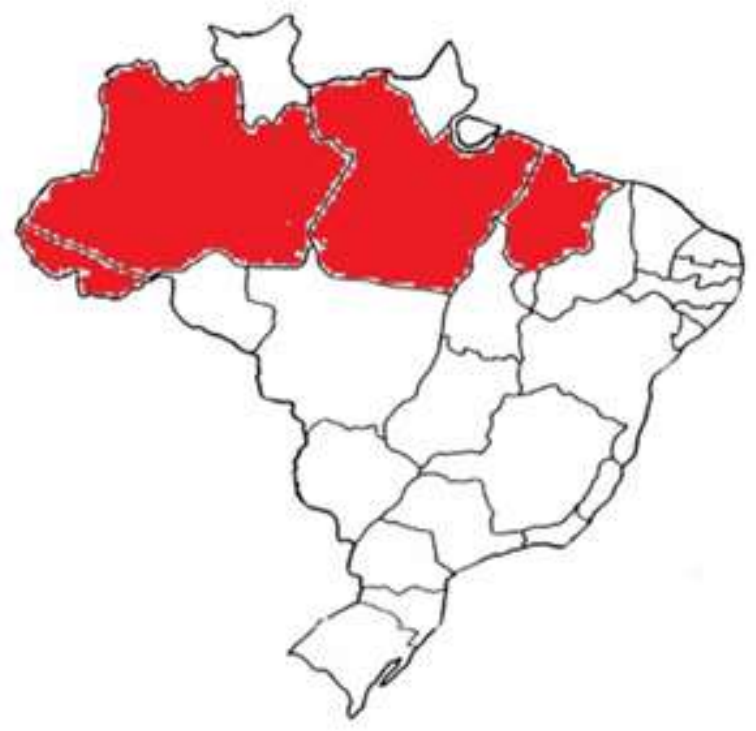

(B)

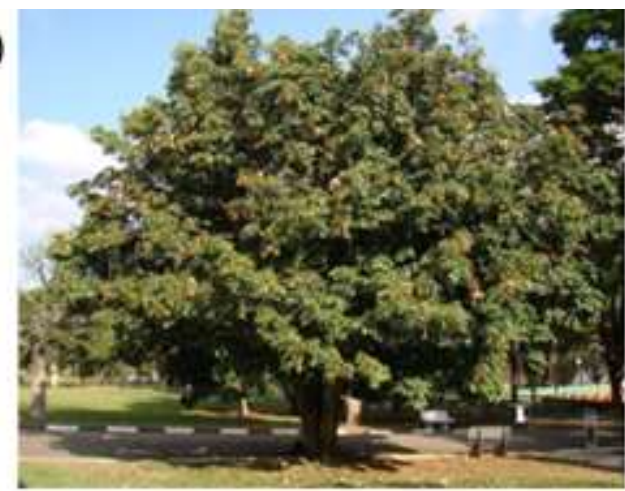

(A)

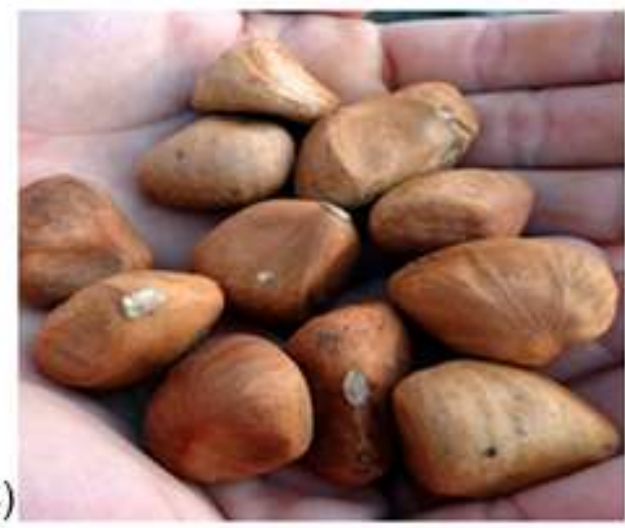

Source: Aracno (2017).

Thus, analyzing the production of biodiesel as an alternative for sustainable development, and the search for new options for raw materials as viable as soybeans, this study aimed to extract oil from the seeds of Pachira aquatica Aubl; evaluate the 
physical chemistry characteristics of the oil and define the best conditions for the catalytic mixture and temperature variation in the production of biodiesel from the oil obtained

\section{Methodology}

\subsection{Seed preparation and oil extraction}

The seeds of Pachira aquatica Aubl were obtained from a rural property in the municipality of Mirante do Paranapanema (UTM $22^{\circ} 17^{\prime}$ 3” S; $51^{\circ} 54^{\prime} 21^{\prime}$ N), in the São Paulo State. For the oil extraction and biodiesel characterization stages (Figure 2), the seeds were peeled, weighed, and dried in an oven with forced air circulation at $65^{\circ} \mathrm{C}$, for $24 \mathrm{~h}$. Subsequently, the seeds were ground for oil extraction analyses.

For the oil extraction, $150 \mathrm{~g}$ of dry and ground seeds were weighed, separated into 50 envelopes of filter paper with $3 \mathrm{~g}$ each.

After this, each $3 \mathrm{~g}$ envelope was inserted into the rods of the Fat Determination System (Tecnal TE-044), which is a continuous Soxhlet extraction method, where $100 \mathrm{~mL}$ of petroleum ether was added for 90 min at a temperature of $90{ }^{\circ} \mathrm{C}$; then the temperature was increased to $120^{\circ} \mathrm{C}$ for another $40 \mathrm{~min}$, aiming at the total recovery of the Petroleum Ether used.

After total recovery of the solvent, the reboilers were removed from the extractor and taken to a dryer for 120 min, so that the remaining solvent could be evaporate, leaving only the oil and thus allowing the lipid content calculation.

Figure 2. Oil extraction steps and biodiesel characterization.

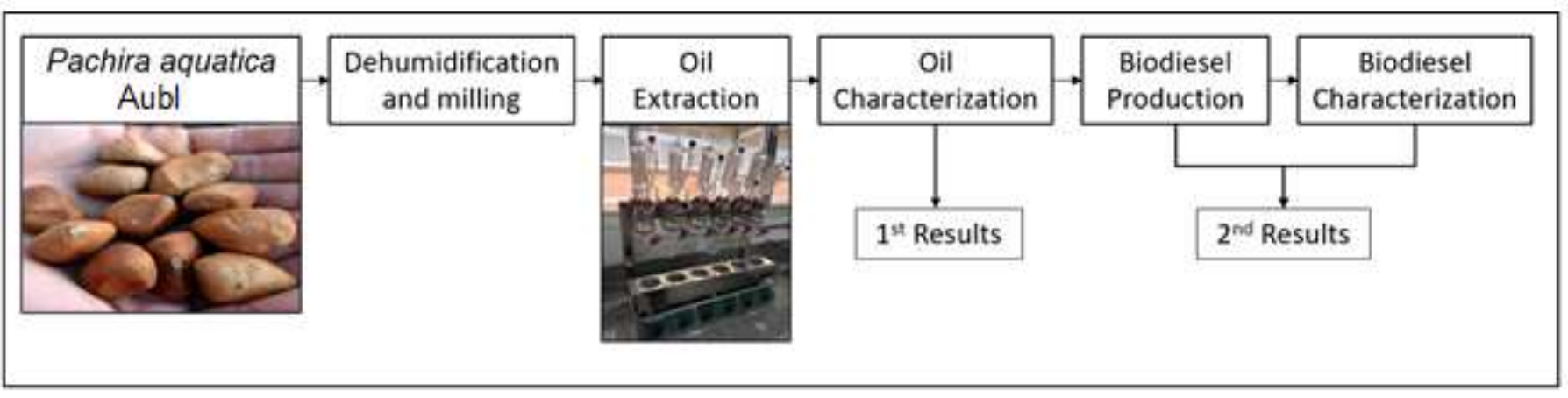

Source: Authors.

\subsection{Physical chemistry analysis of oil}

The oil obtained from seed extraction was evaluated according to international guidelines and by following the physical chemistry analysis described in Table 1.

Table 1. Methods used for the physical chemistry analysis of the oil extracted from the seeds of Pachira aquatica.

\begin{tabular}{cc}
\hline Characteristic & Technical standard/Method \\
\hline Fatty acid profile & Gas Chromatography (Hartman \& Lago, 1973) \\
Acidity index & AOCS Ca 5a-40 (American Oil Chemists' Society - AOCS, 2009) \\
Saponification index & AOCS Cd 3c-91 (AOCS, 2009) \\
Refractive index & AOCS Cc7-25 (AOCS, 2009) \\
Peroxide index & AOCS Cd 8-53 (AOCS, 2009) \\
Water content & EN ISO 12937 (National Agency of Petrol, Natural Gas and Biofuels - ANP, 2012)
\end{tabular}


For the fatty acid profile of the oil, a gas chromatograph with a thermal conductivity detector was used, following the description of the methodology by Hartman and Lago (1973).

To determine the acidity index, the method described by AOCS Ca 5a-40 (AOCS, 2009) was used. It is defined as the amount in milligrams of sodium hydroxide to neutralize $1 \mathrm{~g}$ of oil sample. Erlenmeyer, ethyl alcohol, phenolphthalein indicator was used for the same. determination was used in triplicate. The acidity index was calculated according to Equation 1.

Acidity index $=(\mathrm{V} \times \mathrm{N} \times 2.82) / \mathrm{M}$

Where V: volume spent on titration $(\mathrm{mL}) ; \mathrm{N}$ : exact normality of the NAOH solution; M: sample mass $(\mathrm{g})$; 28.2: correction factor.

The saponification index was determined by the method recommended by ABNT NBR 10448 (ABNT, 2020). It is represented by the amount in milligrams of potassium hydroxide to saponify $1 \mathrm{~g}$ of oil. Erlenmeyer, $0.5 \mathrm{~N}$ potassium hydroxide ethanolic solution, reflux condenser and titrated with $0.5 \mathrm{~N}$ hydrochloric acid in the presence of phenolphthalein were used. The calculation to determine the saponification index was performed by Equation 2 .

$$
\text { Saponification index }=(56.1 \times(\mathrm{V} 0-\mathrm{V} 1) \times \mathrm{Ne}) / \mathrm{m}
$$

Where V0: volume of the hydrochloric acid solution used in the blank test (mL); V1: volume of the hydrochloric acid solution used with the sample $(\mathrm{mL})$; Ne: exact normality of hydrochloric acid; m: sample weight $(\mathrm{g})$.

The refractive index was determined by means of a refractometer, using the methodology of AOCS Cc7-25 (AOCS, 2009). The refractive index is related to the degree of saturation of the molecules, which can be changed due to oil oxidation.

The peroxide index was determined by the method proposed by AOCS Cd 8-53 (AOCS, 2009), from milliequivalents of active oxygen in $1000 \mathrm{~g}$ of oil, calculated from the iodine released from potassium iodide. An Erlenmeyer flask was used, with a 3:2 chloroformic acetic acid solution, $0.05 \mathrm{~mL}$ Potassium Iodide and titrated in the presence of $3 \mathrm{~mL}$ of water with $0.1 \mathrm{~N}$ sodium thiosulfate. For the calculation, Equation 3 was used.

Peroxide index $=((\mathrm{A}-\mathrm{B}) \mathrm{x} \mathrm{N} \times \mathrm{f} \times 1000) / \mathrm{P}$

Where A: volume of sodium thiosulfate solution used in sample titration $(\mathrm{mL})$; B: volume of the sodium thiosulfate solution used in the blank titration $(\mathrm{mL}) ; \mathrm{N}$ : normality of the sodium thiosulfate solution; f: sodium thiosulfate solution factor; P: sample weight $(\mathrm{g})$.

To determine the water content, the Karl Fisher method was used, using the EN ISO 12937 technique (ANP, 2012). This methodology is based on the oxidation of sulfur dioxide by iodine in a methanol solution.

\subsection{Experimental planning and evaluation of biodiesel production}

To obtain biodiesel from munguba, the following method proposed by Johnson and Wen (2009) was used. Fourteen treatments were studied, with methanol solution $\left(\mathrm{CH}_{3} \mathrm{OH}\right)$, chloroform $\left(\mathrm{CHCl}_{3}\right)$, with different concentrations of sulfuric acid $\left(\mathrm{H}_{2} \mathrm{SO}_{4}\right)$ and at different temperatures, as shown in Table 2. 
For the study, $500 \mathrm{mg}$ of oil were used, which were divided into 14 tubes that represented the evaluated treatments. The reaction lasted for $60 \mathrm{~min}$, with 10-min intervals for the tube to be shaken with a Vortex apparatus. After this, the samples were cooled to room temperature, $2 \mathrm{~mL}$ of distilled water was added, and the tubes were allowed to stand for $24 \mathrm{~h}$ for decanting. Then about $1 \mathrm{~mL}$ of the esters produced were removed from the tube and left in a dryer at $90{ }^{\circ} \mathrm{C}$ for 60 min for later analysis.

Table 2. Experimental planning for biodiesel production

\begin{tabular}{ccccc}
\hline Treatment & Methanol $\left(\mathrm{CH}_{3} \mathrm{OH}\right)(\mathrm{mL})$ & Chloroform $\left(\mathrm{CHCl}_{3}\right)(\mathrm{mL})$ & Sulfuric acid $\left(\mathrm{H}_{2} \mathrm{SO}_{4}\right)(\mathrm{mL})$ & Temperature $\left({ }^{\circ} \mathrm{C}\right)$ \\
\hline 1 & 3.4 & 4.0 & 0.4 & 30 \\
2 & 3.4 & 4.0 & 0.6 & 30 \\
3 & 3.4 & 4.0 & 0.8 & 30 \\
4 & 3.4 & 4.0 & 0.4 & 60 \\
5 & 3.4 & 4.0 & 0.6 & 60 \\
6 & 3.4 & 4.0 & 0.8 & 60 \\
7 & 3.4 & 4.0 & 0.4 & 90 \\
8 & 3.4 & 4.0 & 0.6 & 90 \\
9 & 3.4 & 4.0 & 0.8 & 90 \\
\hline
\end{tabular}

Source: Authors.

\subsection{Physical chemistry analysis of biodiesel}

The biodiesel produced also followed technical standards for its physical chemistry characterization (Table 3).

Table 3. Methods used for the physical chemistry analysis of biodiesel of Pachira aquatica

\begin{tabular}{cc}
\hline Physical chemistry characteristic & Technical standard/Method \\
\hline Specific mass & ASTM D 4052 (ANP, 2012) \\
Kinematic Viscosity at $40^{\circ} \mathrm{C}$ & ASTM D 445 (ANP, 2012) \\
Ester Content & Gas Chromatography (ANP, 2012) \\
Refractive index & AOCS Cc7-25 (AOCS, 2009) \\
Water content & EN ISO 12937 (ANP, 2012) \\
\hline
\end{tabular}

Source: Authors.

The specific mass at $20^{\circ} \mathrm{C}$ was obtained using a pycnometer apparatus. This apparatus determines the specific mass of the substance by the ratio between mass and volume.

Kinematic viscosity was determined using a Cannon-Fenkse viscometer in a thermostatic bath at $40{ }^{\circ} \mathrm{C}$. Kinematic viscosity is a property that is directly linked to the fluid's resistance to flow, under a given time.

PerkinElmer, model "Clarus 680GC," was the gas chromatograph, with a thermal conductivity detector, used to evaluate fatty acid profile and ester content, according to the standards of ABNT 15764 (ANP, 2012).

The determination of the refractive index and the water content present in the biodiesel production was carried out according to the same methodology previously described for the analysis of the oil of Pachira aquatica. 


\subsection{Statistical analysis}

Data analysis to define the ideal conditions for experimental planning was performed by applying the response surface methodology and adjusting the variance model using the Statistical Software (version 10), with a significance level of 5\%, to evaluate the influence that sulfuric acid and temperature have in the Pachira aquatica biodiesel production.

\section{Results and Discussion}

\subsection{Characterization of Pachira aquatica oil}

\subsubsection{Physical chemistry analysis}

Table 4 presents the results found for the lipid content, indexes of acidity, saponification, refraction, saponification, and water content. The lipid content of $43.14 \%$ was higher than that found in other studies, such as the one by Jorge and Luzia (2012), who found 38.39\%, and was lower than Silva (2010), with 46.62\%, and Lago, Pereira, Siqueira, Szpiz and Oliveira (1986), with $44.1 \%$. The lipid content of $43.11 \%$, found in the seeds of Pachira aquatica, is considered high compared to other oilseeds, such as soybean, with values between 16 and $22 \%$, and is the main source of raw material for the production of biodiesel.

Table 4. Results found during the physical chemistry characterization of Pachira aquatica oil

\begin{tabular}{cccccc}
\hline $\begin{array}{c}\text { Lipid content } \\
(\%)\end{array}$ & $\begin{array}{c}\text { Acidity index } \\
(\mathrm{mg} \mathrm{KOH} / \mathrm{g})\end{array}$ & $\begin{array}{c}\text { Saponification index } \\
(\mathrm{mg} \mathrm{KOH} / \mathrm{g})\end{array}$ & $\begin{array}{c}\text { Refractive } \\
\text { index }\left(40{ }^{\circ} \mathrm{C}\right)\end{array}$ & $\begin{array}{c}\text { Peroxide index } \\
\left(\mathrm{meq} \mathrm{kg}^{-1}\right)\end{array}$ & $\begin{array}{c}\text { Water content } \\
(\%)\end{array}$ \\
\hline 43.14 & 3.283 & 180.95 & 1.4656 & 0.993 & 2.1 \\
\hline
\end{tabular}

Source: Authors.

The acidity index of the oil was found $3.283 \mathrm{mg} \mathrm{KOH} / \mathrm{g}$, this value is much lower when compared to other oils, such as peanut, with $4.88 \mathrm{mg} \mathrm{KOH} / \mathrm{g}$, sunflower, with $8.73 \mathrm{mg} \mathrm{KOH} / \mathrm{g}$, and andiroba, with $17.74 \mathrm{mg} \mathrm{KOH} / \mathrm{g}$ (Radunz et al., 2018 ; Rovere, Rodrigues \& Teleken, 2020). The National Health Surveillance Agency - ANVISA establishes that oils considered good must have a maximum value of $4.0 \mathrm{mg} \mathrm{KOH} / \mathrm{g}$ (ANVISA, 2005).

The acidity index is a very important characteristic for the biodiesel production process, in addition to providing the degree of oil degradation (Morais, Christiani, Cestari \& Flumignan, 2012). If the acidity is high, it can catalyze intermolecular reactions, which can affect the thermal stability of the fuel in the combustion chamber and increase the corrosive action in the engine (Silva, 2005).

The acidity index is linked to the level of degradation of the oil quality, which is directly related to the nature of the raw material and the degree of purity of the oil (Ngassapa, Nyandoro \& Mwaisaka, 2012). Oils with high acidity content when inserted in the production process of biodiesel does not have a phase separation (ester and glycerin) (Nunes, 2007).

The value found for the saponification index was $180.95 \mathrm{mg} \mathrm{KOH} / \mathrm{g}$. This value was very close to that found by Silva (2010) of $172 \mathrm{mg} \mathrm{KOH} / \mathrm{g}$ and lower than those obtained by Jorge and Luzia (2012), of $208 \mathrm{mg} \mathrm{KOH} / \mathrm{g}$ for the same species. When compared to other oilseeds, such as soybean, with values of $143.32 \mathrm{mg} \mathrm{KOH} / \mathrm{g}$ (Almeida, Nunes, Teixeira, Rodrigues \& Mello, 2011) and sesame, with $142.2 \mathrm{mg} \mathrm{KOH/g} \mathrm{(Dawodu,} \mathrm{Ayodele} \mathrm{\&} \mathrm{Bolanle-Ojo,} \mathrm{2014),} \mathrm{the} \mathrm{saponification} \mathrm{index} \mathrm{of} \mathrm{Pachira}$ aquatica was higher.

The refractive index obtained in the present study was 1.4656. This value is comparable to that reported by Jorge and Luzia (2012), of 1.4549 for Pachira aquatica oil. The refractive index is related to the degree of unsaturation of bonds, oxidation compounds and thermal treatment, reflecting on the number of double bonds and the size of hydrocarbon chains (Almeida et al., 2011; Jorge, Soares, Lunardi \& Malacrida, 2005). 
The peroxide index value found was $0.993 \mathrm{meq} \mathrm{kg}^{-1}$. On the other hand, Jorge and Luzia (2012) found zero value for this index, and in our case, it was lower in comparison with other oils such as peanut, with 3.64 meq kg-1 (Radunz et al., 2018) and Jatropha curcas L., with 2.77 meq kg-1 (Moura et al., 2019). The peroxide index is an essential parameter to estimate the degree of deterioration of the raw material, which occurs due to the change in the color and odor of biodiesel (Oliveira, Cremonez, Feroldi, Weiser Meier \& Teleken, 2015).

The water content found for Pachira aquatica oil was $2.1 \%$ lower than that found by Jorge and Luzia (2012), which was $3.89 \%$, and higher than other oils such as babassu, with $0.36 \%$ and pequi, with $0.31 \%$ (Vieira et al., 2018). A content higher than $0.5 \%$ can cause hydrolysis of triglycerides, converting them to free fatty acids (Barros, Wust \& Meier, 2008).

\subsubsection{Fatty acids profile}

The fatty acids profile (Figure 3) showed the predominance of palmitic acid with $81.95 \%$ (Table 5). Jorge and Luzia (2012) and Oliveira (2018) also indicated that the presence of palmitic acid stood out in their studies, with values of $69.4 \%$ and 44.93\%, respectively. Pachira aquatica oil is mostly composed of saturated fatty acids, and this reflects on the size of chains and bonds among molecules. Table 5 presents the results obtained for the components present in Pachira aquatica oil.

Figure 3. Chromatographic profile of fatty acids in Pachira aquatica Aubl oil

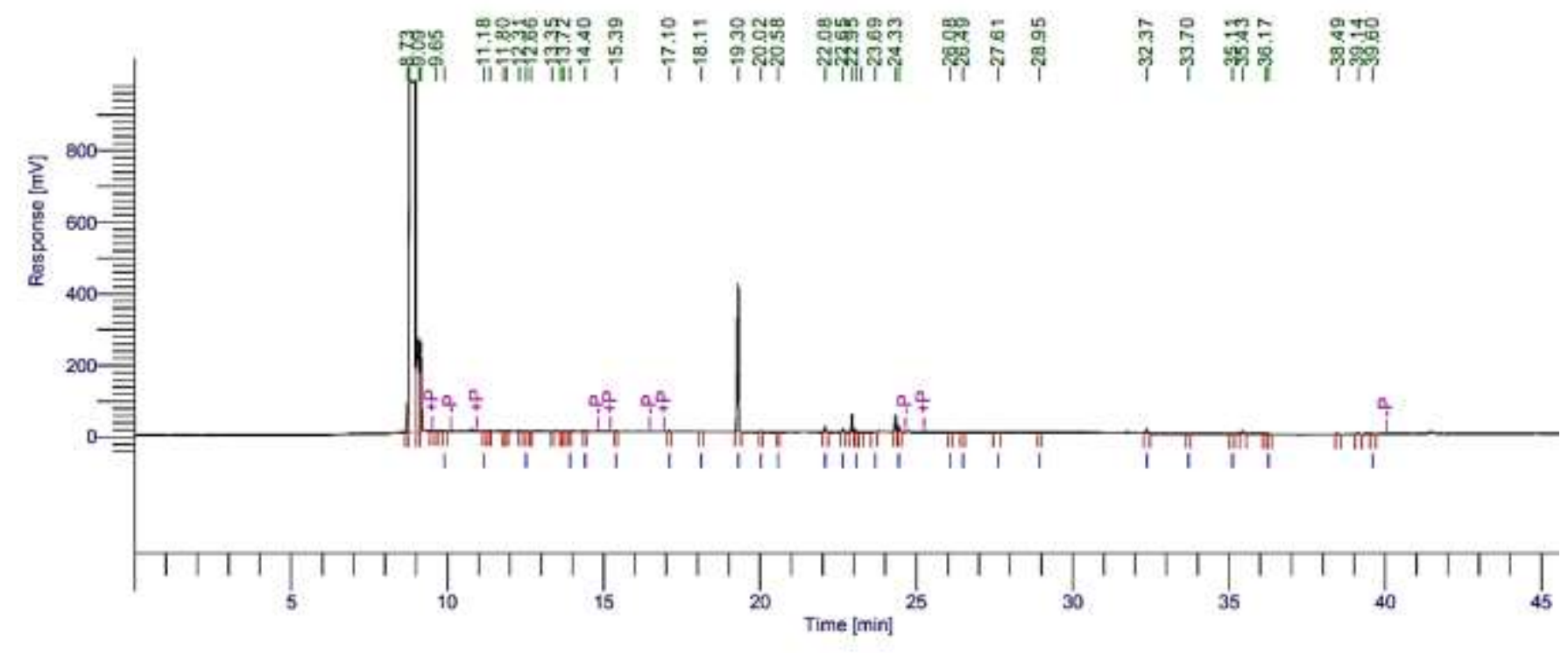

Source: Authors. 
Table 5. Identification of components in Pachira aquatica Aubl.

\begin{tabular}{|c|c|c|}
\hline Analyte Name & Time [min] & Norm. area $(\%)$ \\
\hline C4 (Butyric Acid) & 9.895 & 0.19 \\
\hline C6 (Caproic Acid) & 11.184 & 0.27 \\
\hline C8 (Caprylic Acid) & 12.522 & 0.29 \\
\hline C10 (Cirtic Acid) & 13.921 & 0.20 \\
\hline C11 (Acid hendecanóico) & 14.401 & 0.09 \\
\hline C12 (Lauric acid) & 15.393 & 0.25 \\
\hline C14 (Meristic Acid) & 17.101 & 0.48 \\
\hline C15 (Pentadecyl Acid) & 18.111 & 0.11 \\
\hline C16 (Palmitic acid) & 19.303 & 81.95 \\
\hline C16:1 ( Palmitoleic Acid) & 20.023 & 0.37 \\
\hline C17 (Margaric Acid) & 20.576 & 0.19 \\
\hline C18 (Stearic Acid) & 22.085 & 3.08 \\
\hline C18: 1N9T (Acid elaídico) & 22.652 & 1.75 \\
\hline C18: 1N9C (Oleic Acid) & 23.082 & 1.07 \\
\hline C18:2N6T (Acid linolelaídico) & 23.694 & 0.49 \\
\hline C18:2N6C (Linoleic Acid) & 24.439 & 3.49 \\
\hline C18:3N3 (Acid $\alpha$ Linoleic) & 26.079 & 0.30 \\
\hline C20:1 (Acid Gadoléico) & 26.488 & 0.50 \\
\hline $\mathrm{C} 21$ & 27.614 & 0.44 \\
\hline $\mathrm{C} 20: 2$ & 28.946 & 0.28 \\
\hline $\mathrm{C} 23$ & 32.370 & 2.90 \\
\hline $\mathrm{C} 22: 2$ & 33.698 & 0.18 \\
\hline C24 (Lignoceric Acid) & 35.106 & 0.41 \\
\hline $\mathrm{C} 22: 3 \mathrm{~N} 3$ & 36.261 & 0.33 \\
\hline \multirow[t]{2}{*}{ C24: 1N9 ( Nervonic Acid) } & 39.600 & 0.38 \\
\hline & & 100.00 \\
\hline
\end{tabular}

Source: Authors.

\subsection{Biodiesel from Pachira aquatica oil}

\subsubsection{Physical chemistry analysis}

After the production of biodiesel, the physical chemistry analyzes started with the kinematic viscosity at $40{ }^{\circ} \mathrm{C}$ and presented a value of $7.44 \mathrm{~mm}^{2} / \mathrm{s}$ (Tabele 6). While Souza (2008) found values of $6.23 \mathrm{~mm}^{2} / \mathrm{s}$. When compared to biodiesel from soy, $3.97 \mathrm{~mm}^{2} / \mathrm{s}$ (Alptekin \& Canack, 2008) and from jatropha, $2.47 \mathrm{~mm}^{2} / \mathrm{s}$ (Patil \& Deng, 2009), the value of biodiesel from Pachira aquatica was much higher. The ANP (2014) establishes in its standards that the ideal kinematic viscosity for the production of biodiesel must present values between 3 to $6 \mathrm{~mm} / \mathrm{s}$; thus, pure Pachira aquatica biodiesel, without any mixtures, would not meet the ANP requirements.

The water content found was $192 \mathrm{mg} / \mathrm{kg}$, meeting the required by ANP (2014) of $200 \mathrm{mg} / \mathrm{kg}$. This parameter is directly linked to the biodiesel purification process. If the water content is not within the parameters regulated standard, it can lead to corrosion of the fuel tank, and proliferation of microorganisms. 
When the specific mass at $20^{\circ} \mathrm{C}$ is above the levels established by the ANP (2014), which limits values between 850 and $900 \mathrm{~kg} / \mathrm{m}^{3}$, can occur to the emission of pollutants, such as CO and other particulate materials. However, if this content is too low, fuel consumption in biodiesel vehicles may increase. In the present study, the specific mass value was $901.9 \mathrm{~kg} / \mathrm{m}^{3}$. The value found was lower compared to the result obtained by Souza (2008) of $916.8 \mathrm{~kg} / \mathrm{m}^{3}$ and higher than the results obtained by Brum et al. (2009), $889.8 \mathrm{~kg} / \mathrm{m}^{3}$ for biodiesel from $P$. aquatica.

Table 6. Physical chemistry analysis Pachira aquatica Aubl.

\begin{tabular}{ccc}
\hline Physical chemistry analysis & Result & ABNT \\
\hline Kinematic viscosity $\left(40^{\circ} \mathrm{C}\right)$ & $7.44 \mathrm{~mm}^{2} / \mathrm{s}$ & ANP $(2014)\left(3 \mathrm{a} 6 \mathrm{~mm}^{2} / \mathrm{s}\right)$ \\
Water Content & $192 \mathrm{mg} / \mathrm{kg}$ & ANP (2014) $(200 \mathrm{mg} / \mathrm{kg})$ \\
Specific Mass at $20^{\circ} \mathrm{C}$ & $901,9 \mathrm{~kg} / \mathrm{m}^{3}$ & ANP $(2014)\left(800-900 \mathrm{~kg} / \mathrm{m}^{3}\right)$ \\
\hline
\end{tabular}

Source: Authors.

\subsubsection{Ester's content}

Considering the yields of each one of the treatments, the highest content of biodiesel was achieved at $60{ }^{\circ} \mathrm{C}$ and with $0.6 \mathrm{~mL}$ of sulfuric acid. These results corroborate those observed by Johnson and Wen (2009).

Table 7 shows the values of methyl esters $(\mathrm{mL})$ and conversion rate $(\%)$ found in the 14 treatments studied. Table 8 shows the methyl esters present in biodiesel from Pachira aquatica. In Figure 4, the relation of temperature $\mathrm{x}_{2} \mathrm{SO}_{4}$ can be seen as a function of the amount of methyl ester produced.

Table 7. Conversion rate and amount of methyl esters $(\mathrm{mL})$ produced from the Pachira aquatica biodiesel production process.

\begin{tabular}{ccccc}
\hline Treatment & Sulfuric acid $(\mathrm{mL})$ & Temperature $\left({ }^{\circ} \mathrm{C}\right)$ & Methyl esters $(\mathrm{mL})$ & Conversion rate $(\%)$ \\
\hline 1 & 0.4 & 30 & 376.0 & 75.20 \\
2 & 0.6 & 30 & 414.8 & 82.96 \\
3 & 0.8 & 30 & 395.6 & 79.12 \\
4 & 0.4 & 60 & 424.6 & 84.92 \\
5 & 0.6 & 60 & 431.2 & 86.24 \\
6 & 0.8 & 60 & 411.6 & 82.32 \\
7 & 0.4 & 90 & 400.4 & 80.08 \\
8 & 0.6 & 90 & 425.0 & 85.00 \\
9 & 0.8 & 90 & 431.4 & 86.28 \\
\hline
\end{tabular}

Source: Authors.

Table 8. Methyl ester found in the gas chromatography of biodiesel from Pachira aquatica Aubl.

\begin{tabular}{ccc}
\hline Methyl ester & Structure & Value found (\%) \\
\hline Methyl palmitate & C 16:0 & 64.1 \\
Methyl stearate & C 18:0 & 3.9 \\
Methyl oleate & C 18:1 & 12.2 \\
Methyl linoleate & C 18:2 & 8.3 \\
\hline
\end{tabular}


Concerning conversion rate (Table 7), treatment 1 , at $30^{\circ} \mathrm{C}$ and with $0.4 \mathrm{~mL}$ of sulfuric acid, produced less methyl esters, with 75.20\%; this value is due to the fact that its composition has the less amount of sulfuric acid (0.4) and the temperature being the lowest of all used $\left(30^{\circ} \mathrm{C}\right)$. Treatment 9 , at $60^{\circ} \mathrm{C}$ and with $0.8 \mathrm{~mL}$ of sulfuric acid showed the highest conversion rate, with $86.24 \%$. It should have undergone a purification or even be repeated several times for the yield to increase.

As for the esters, it was found that methyl palmitate stood out in the production of biodiesel, with $64.1 \%$, followed by methyl oleate, with 12.2\% (Table 8). In their studies, Souza (2008) and Brum et al. (2009) also observed higher contents of methyl palmitate esters (65.7 and 68.3\%, respectively) and methyl oleate (15.8 and 10\%, respectively).

The difference between the acids found in biodiesel and oil varied thanks to the process that it went through, influenced by the sulfuric acid used and other compounds.

Figure 4. Graph (response surface) of ester conversion rate.

Fitted Surface; Variable: Biodiesel

2 3-level factors, 1 Blocks, 14 Runs; MS Pure Error $=49,024$

DV: Biodiesel

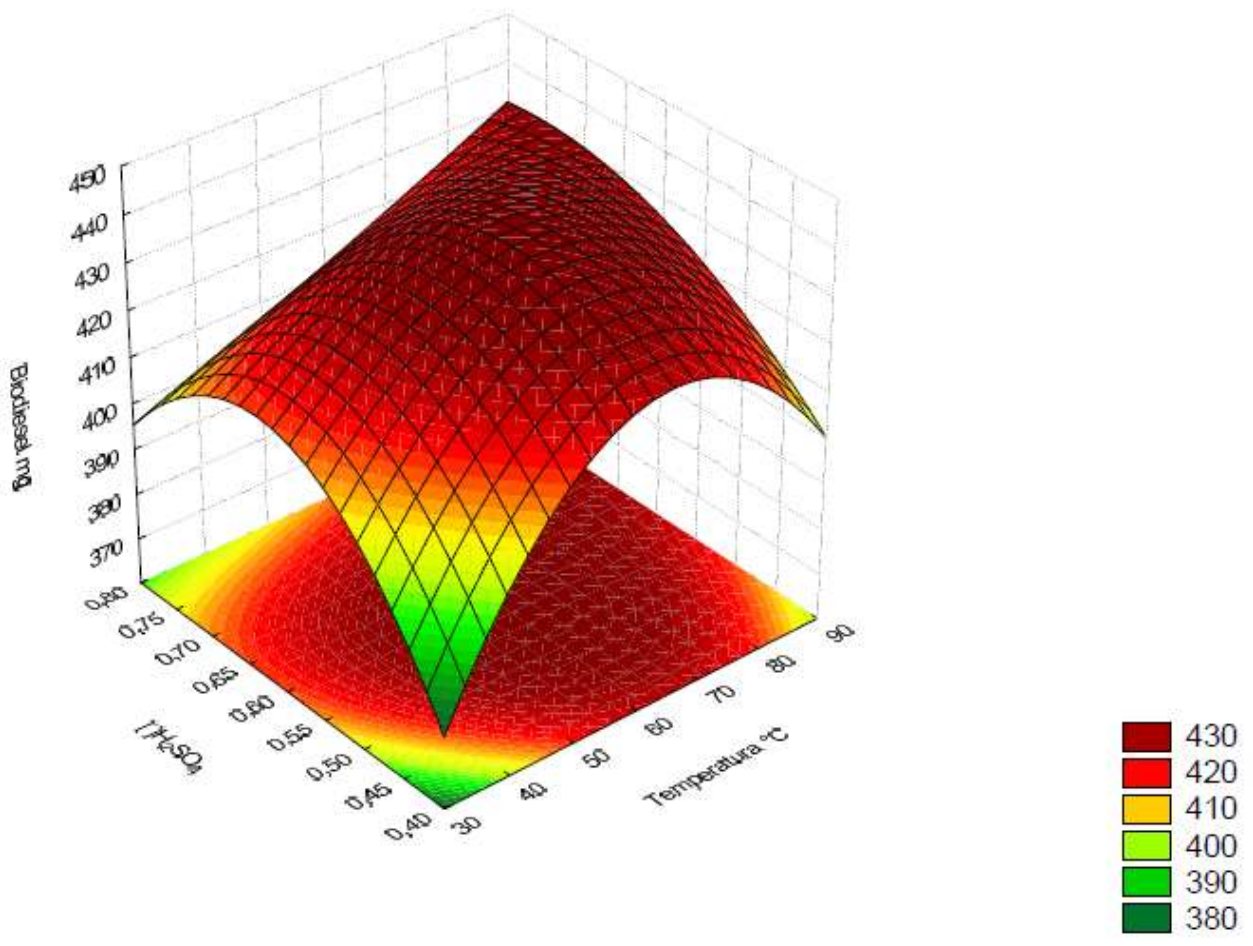

Source: Authors.

The variance test (Table 9) had p-value $=0.07$ and $\mathrm{F}$-value $=4.44$ for the relation between temperature and content of sulfuric acid, which demonstrates a dependence between these variables, where the temperature and sulfuric acid had a significant effect on the conversion of oil to methyl esters, at a 5\% significance level.

The response curve (Figure 4) and Table 7 show that biodiesel production can increase with higher temperatures and content of sulfuric acid $\left(60{ }^{\circ} \mathrm{C}\right.$ and $\left.0.6 \mathrm{~mL}\right)$. However, above these values, the conversion rate of esters decreases. 
Table 9. Variance test to evaluate the dependence of variables considered in the biodiesel production.

\begin{tabular}{cccccc}
\hline Factor & SS & df & MS & F & P \\
\hline (1) Temperature L + Q & 1594.470 & 2 & 797.2349 & 16.26213 & 0.006481 \\
$(2) \mathrm{H}_{2} \mathrm{SO}_{4} \mid$ & 1348.388 & 2 & 674.1938 & 13.75232 & 0.009280 \\
$1 * 2$ & 653.457 & 3 & 217.8189 & 4.44311 & 0.070999 \\
Lack of fit & 1.4184 & 1 & 1.44841 & 0.03027 & 0.868697 \\
Pure Error & 245.120 & 5 & 49.024 & & \\
Total SS & 5441.477 & 13 & & & \\
\hline
\end{tabular}

Source: Authors.

\section{Conclusion}

Pachira aquatica Aubl seeds have high lipid content (average $=42.19 \%$ ). The physical chemistry analysis showed that Pachira aquatica oil is an alternative for the production of biofuels. There was a greater presence of saturated fatty acids, with a predominance of $81.95 \%$ for palmitic acid. The method used showed higher percentage of esters in relation to the volume used at $60{ }^{\circ} \mathrm{C}$ and with $0.6 \mathrm{ml}$ of sulfuric acid. The physical chemistry properties of biodiesel from Pachira aquatica confirmed the oil's potential as an alternative in production, since all physical chemistry properties are within the limits of what is required by national and international guidelines. However, further studies are necessary to prove the viability of this species, considering oil extraction, storage, and biodiesel production.

\section{Acknowledgments}

The authors are grateful to the State University of Western Paraná, Cascavel campus; State University of Londrina; Faculty of Higher Education of São Miguel do Iguaçu and Federal Technological University of Paraná, Medianeira campus .

\section{References}

ABNT. (2020). Associação Brasileira de Normas Técnicas. NBT 10448. Insumos - Substâncias graxas - Determinação do índice de saponificação, de 31 de julho de 2020. São Paulo: ABNT.

Almeida, J. K. P., Nunes, G. P., Teixeira, C. C. M., Rodrigues, D. P., \& Mello, J. R. (2011). Caracterizações fisico-químicas de óleos vegetais utilizados para produção de biodiesel com metodologias alternativas simples. In: XXXI Encontro Nacional de Engenharia de Produção. Inovação Tecnológica e Propriedade Intelectual: Desafios da Engenharia de Produção na Consolidação do Brasil no Cenário Econômico Mundial. 2011. Belo Horizonte. Retrieved on May 10, 2019. http://www.abepro.org.br/biblioteca/enegep2011_TN_STP_135_855_18349.pdf.

ANVISA. (2005). Agência Nacional de Vigilância Sanitária. Regulamento técnico para óleos vegetais, gorduras vegetais e creme vegetal. Resolução RDC $n^{o}$ 270, de 22 de setembro de 2005. Brasília: Agência Nacional de Vigilância Sanitária.

Alptekin, E., \& Canack, M. (2008). Determination of the density and the viscosities of biodiesel-diesel fuel blends. Renewable Energy, 33, 2623-2630. doi: $10.1016 /$ j.renene.2008.02.020

AOCS. (2009). American Oil Chemists' Society. Official Methods and Recommended Practices of the American Oil Chemists' Society. Champaign. Retrieved on May 10, 2019.

ANP. (2019). National Agency of Petrol, Natural Gas and Biofuels. Biocombustíveis. http://www.anp.gov.br/biocombustiveis.

ANP. (2020). National Agency of Petrol, Natural Gas and Biofuels. Produção Biodiesel. http://app.powerbi.com/view?r=eyJrljoiOTIkODYyODctMGJjNS00MGIyLWJmMWItNGJINDg0ZTg5NjBIIiwidCI6IjQ0OTlmNGZmLTI0YTYtNGI0Mi1i N2VmLTEyNGFmY2FkYzkxMyJ9\&pageName=ReportSection8aa0cee5b2b8a941e5e0".

ANP. (2012). National Agency of Petrol, Natural Gas and Biofuels. Resolução n 14, de 11, de maio de 2012. Retrieved on May 10, 2019. http://www.anp.gov.br. ANP. (2014). National Agency of Petrol, Natural Gas and Biofuels. Resolução n 45, de 25, de agosto de 2014. http://www.anp.gov.br.

Aracno R. (2017). Aracno Garden: Falso-cacau ou Munguba. http://aracnogarden.blogspot.com/2017/06/falso-cacau-ou-munguba.html.

Barros, A. A. C., Wust, E., \& Meier, H. F. (2008). Estudo da viabilidade técnico-científica da produção de biodiesel a partir de resíduos gordurosos. Engenharia 
Sanitária e Ambiental, 13 (3), 255-262. doi: 10.1590/S1413-41522008000300003.

Bergmann, J. C., Tupinambá, D. D., Costa, O. Y. A., Almeida, J. R. M., Barreto, C. C., \& Quirino, B. F. (2013). Biodiesel production in Brazil and alternative biomass feedstocks. Renewable and Sustainable Energy Reviews, 21, 411-420. doi: 10.1016/j.rser.2012.12.058.

Brum, M. C., Santos, L. S., Santos, R. B., Lacerda Junior, V., Greco, S. J., \& Castro, E. V. R. (2009). Biodiesel da munguba (Pachira aquatica Aubl). Síntese e avaliação da presença de ácidos graxos ciclopropenoídicos. Sociedade Brasileira de Química. 2009. http://sec.sbq.org.br/cdrom/32ra/lista_area_TC.htm.

Camacho, M. M. E., Tatis, H. A., \& Ayala, C. C. (2018). Correlations and path analysis between fruit characteristics and seeds of Pachira aquatica Aubl. Revista Facultad Nacional de Agronomía Medellín, 71, 8387-8394. http://www.revistas.unal.edu.co/index.php/refame.

Cavalett, O., \& Ortega, E. (2009). Emergy, nutrients balance, and economic assessment of soybean production and industrialization in Brazil. Journal of Cleaner Production, 17, 762-771. doi: 10.1016/j.jclepro.2008.11.022.

Dawodu, F. A., Ayodele, O. O., \& Bolanle-Ojo, T. (2014). Biodiesel production from Sesamum indicum L. seed oil: An optimization study. Egyptian Journal of Petroleum, 23, 191-199. doi: 10.1016/j.ejpe.2014.05.006.

Ferrari, R. A., Oliveira, V. D., \& Scabio, A. (2005). Biodiesel de soja - taxa de conversão em ésteres etílicos, caracterização físico-química e consumo em gerador de energia. Química Nova, 28, 19-23. doi: 10.1590/S0100-40422005000100004.

Hartman, L., \& Lago, R. C. (1973). Rapid preparation of fatty acid methyl esters from lipids. Laboratory Practice, 22, $475-476$ passim PMID: 4727126.

Johnson, M. B., \& Wen, Z. (2009). Production of biodiesel fuel from the microalga Schizochytrium limacinum by direct transesterification of algal biomass. Energy Fuels, 23, 5179-5183. doi: 10.1021/ef900704h.

Jorge, N., \& Luzia, D. M. M. (2012). Caracterização do óleo das sementes de Pachira aquatica Aublet para aproveitamento alimentar. Acta Amazônica, 42, 149156. doi: 10.1590/S0044-59672012000100017.

Jorge, N., Soares, B. B. P., Lunardi, V. M., \& Malacrida, C. R. (2005). Alterações físico-químicas dos óleos de girassol, milho e soja em frituras. Química Nova, 28, 947-951. doi: 10.1590/S0100-40422005000600003.

Knothe, G., Gerpen, J., \& Krahl, J. (2005). The Biodiesel Handbook. New York: Academic Press and AOCS Press.

Kohlhepp, G. (2010). Análise da situação da produção de etanol e biodiesel no Brasil. Estudos Avançados, 24, 223-253. doi: 10.1590/S010340142010000100017.

Lago, R. C. A., Pereira, D. A., Siqueira, F. A. R., Szpiz, R. R., \& Oliveira, J. P. (1986). Estudo preliminar das sementes $\varepsilon$ do óleo de cinco espécies da amazônia. Acta Amazonica, 17, 369-376. doi: 10.1590/1809-43921986161376.

Lima Filho, L. R., Gouveia, L. G. T., Ruzene, D. S., \& Silva, D. P. (2017). Revisão: Biodiesel - gases emitidos, produção e sua influência na matriz energética brasileira. In: IX Simpósio de Engenharia de Produção de Sergipe. 2017. São Cristóvão: DEPRO/UFS, 559-567. Retrieved on Jun 19, 2018. https://ri.ufs.br/bitstream/riufs/7621

Lorenzi, H. (1992). Árvores Brasileiras: manual de identificação e cultivo de plantas arbóreas nativas do Brasil. Editora Plantarum Ltda. São Paulo: Nova Odessa.

Ma, F., \& Hanna, M. A. (1999). Biodiesel production: a review. Bioresource Technology, 70, 1-15. doi: 10.1016/S0960-8524(99)00025-5.

Matos, M. A., Ninaut, E. S., Caiado, R. C., \& Salvi, J. V. (2008). A Elevação dos Preços das Commodities Agrícolas e a questão da agroenergia. Informações Econômicas, 38, 68-83.. http://www.iea.sp.gov.br/ftpiea/publicacoes/tec7-0908.pdf.

Mitchell, D. (2008). A note on rising food prices. Policy Research Working Papers, 7, 1-21. doi: 10.1596/1813-9450-4682.

Morais, A. L., Christiani, G., Cestari, A., \& Flumignan, D. L. (2012). Caracterização da identidade e controle da qualidade de óleo vegetal, matéria-prima para produção de biodiesel. In: VI Infobibos. https://www.infobibos.com/anais/agroenergia/6/resumos/ResumoAgroenergia_2012_064.pdf.

Moura, C. V. R., Silva, B. C., Castro, A. G., Moura, E. M., Veloso, M. E. C., Sittolin, I. M., \& Araujo, E. C. E. (2019). Caracterização físico-química de óleos vegetais de oleaginosas adaptáveis ao nordeste brasileiro com potenciais para produção de biodiesel. Revista Virtual de Química, 11, 573-595. http://rvq.sbq.org.br.

Ngassapa, F., Nyandoro, S. S., \& Mwaisaka, T. R. (2012). Effects of temperature on the physicochemical properties of traditionally processed vegetable oils and their blends. Tanzania Journal of Science, 38, 166-176. https://www.ajol.info/index.php/tjs/article/view/100188.

Nunes, S. P. (2007). Produção e consumo de óleos vegetais no Brasil. Departamento de Estudos Sócio-Econômicos Rurais. Boletim eletrônico, 159, 1-10. Retrieved on Sep 9, 2018. https://www.fas.usda.gov.

Oliveira, C. D. J., Cremonez, P. A., Feroldi, M., Weiser Meier, T. R., \& Teleken, J. G. (2015). Comparação da variação do índice de peróxido e massa específica das misturas de ésteres a partir do óleo de pequi após diferentes tempos de fritura. Revista Gestão \& Sustabilidade Ambiental, 4, 482-497. doi: 10.19177/rgsa.v4e02015482-497.

Oliveira, L. P. (2018). Estudo de oleaginosas alternativas para a produção de biodiesel e bio-óleo. Dissertação de Mestrado. Programa de Pós-Graduação em Tecnologias Química e Biológica, Universidade de Brasília, Brasília. 62p.

Patil, P. D., \& Deng, S. (2009). Optimization of biodiesel production from edible and non-edible vegetable oils. Fuel, 88, 1302-1306. doi: 10.1016/j.fuel.2009.01.016. 
Radunz, M., Hackbart, H. C. S., Ribas, B. L. P., Dobke, F. V., Radünz, A. L., \& Mendonça, C. R. B. (2018). Avaliação de parâmetros de qualidade de óleos exóticos. Revista da Jornada de Pós-Graduação e Pesquisa, 15, 367-382. http://trabalhos.congrega.urcamp.edu.br/index.php/14jpgp/article/view/2031.

Ramos, L. P., Kothe, V., César-Oliveira, M. A. F., Muniz-Wypych, A. S., Nakagaki, S., Krieger, N., Wypych, F., \& Cordeiro, C. S. (2017). Biodiesel: matériasprimas, tecnologias de produção e propriedades combustíveis. Revista Virtual de Química, 9, 317-369. http://rvq.sbq.org.br.

Rico, J. A. P., \& Sauer, I. L. (2015). A review of Brazilian biodiesel experiences. Renewable and Sustainable Energy Reviews, 45, 513-529. doi: 10.1016/j.rser.2015.01.028.

Rovere, B. O., Rodrigues, J. H., \& Teleken, J. G. (2020). Redução do índice de acidez através da neutralização e esterificação para produção de biodiesel. Brazilian Journal of Development, 6, 24678-24686. doi: 10.34117/bjdv6n5-064.

Silva, B. D. L. D. A. (2010). Caracterização lipídica e protéica das amêndoas da munguba (Pachira aquatica Aubl.). http://livros01.livrosgratis.com.br/cp073252.pdf.

Silva, C. L. M. (2005). Obtenção de ésteres etílicos a partir da transesterificação do óleo de andiroba com etanol. Dissertação de Mestrado. Programa de PósGraduação em Química Inorgânica, Universidade Estadual de Campinas, Campinas. 64p.

Silva, K. B., Alves, E. U., Matos, V. P., \& Bruno, R. L. A. (2012). Caracterização morfológica de frutos, sementes e fases da germinação de Pachira aquatica Aubl. (Bombacaceae). Semina: Ciências Agrárias, 33, 891-898. doi: 10.5433/1679-0359.2012v33n3p891.

Silva, M. A. A., Borges, A. T. D., \& Antoniosi Filho, N. R. (2015). Development of an assay for qualitative analysis of biodiesel in diesel-biodiesel blends to be applied in petrol stations. Química Nova, 39, 100-103. doi: 10.5935/0100-4042.20150165.

Souza, T. S. (2008). Estudo da transesterificação metílica do óleo da cutieira (Joannesia princeps Vell.) e da munguba (Pachira aquatica Aubl.) em meio alcalino. Dissertação de Mestrado. Programa de Pós-Graduação em Química, Universidade Federal do Espírito Santo, Espírito Santo. 82p.

Vieira, J. S. C., Sousa, T. L., Rosas, L. S., Lima, A. L., Ronconi, C. M., \& Mota, C. J. A. (2018). Esterificação e transesterificação homogênea de óleos vegetais contendo alto teor de ácidos graxos livres. Química Nova, 41, 10-16. doi: 10.21577/0100-4042.20170148.

Vinagre, V. G., Brasil, D. S. B., Corrêa, S. M. V., Santana, E. B., Cordovil, A. B., Silva, C. S. S., Melo, B. L. S., Conceição, G. S., \& Santos, M. L. (2019). Estudo da influência da extração nas propriedades oleoquímicas da Pachira aquatica. In: $16^{\circ}$ Encontro de Profissionais da Química da Amazônica, 2019, Belém. Anais eletronicos, Galoá. Retrieved on Nov 10, 2019. http://proceedings.science/p/108290. 